\title{
Fetal Loss and Hyposulfataemia in Pregnant NaS1 Transporter Null Mice
}

\author{
Paul Anthony DAWSON1), Pearl SIM"), David Gordon SIMMONS') and Daniel MARKOVICH ${ }^{1)}$ \\ ${ }^{1)}$ School of Biomedical Sciences, University of Queensland, Brisbane QLD 4072, Australia
}

\begin{abstract}
Sulfate is important for growth and development, and is supplied from mother to fetus throughout pregnancy. We used NaS1 sulfate transporter null $\left(\mathrm{Nash}^{-7}\right)$ mice to investigate the role of NaS1 in maintaining sulfate homeostasis during pregnancy and to determine the physiological consequences of maternal hyposulfataemia on fetal, placental and postnatal growth. We show that maternal serum $(\leq 0.5 \mathrm{mM})$, fetal serum $(<0.1 \mathrm{mM})$ and amniotic fluid $(\leq 0.5 \mathrm{mM})$ sulfate levels were significantly lower in pregnant $\mathrm{Nas}^{-/-}$mice when compared with maternal serum $(\approx 2.0$ $\mathrm{mM})$, fetal serum $(\approx 1.5 \mathrm{mM})$ and amniotic fluid $(\approx 1.7 \mathrm{mM})$ sulfate levels in pregnant $\mathrm{Nas}^{+/+}$mice. After 12 days of pregnancy, fetal reabsorptions led to markedly reduced (by $\geq 50 \%$ ) fetal numbers in $\mathrm{Nas}^{--}$mice. Placental labyrinth and spongiotrophoblast layers were increased (by $\approx 140 \%$ ) in pregnant $\mathrm{Nas}^{-/}$mice when compared to pregnant $\mathrm{Nas} 1^{+/+}$mice. Birth weights of progeny from female $\mathrm{Nas}^{-\digamma}$ mice were increased (by $\approx 7 \%$ ) when compared to progeny of $\mathrm{Nas}^{+/+}$mice. These findings show that NaS1 is essential to maintain high maternal and fetal sulfate levels, which is important for maintaining pregnancy, placental development and normal birth weight.
\end{abstract}

Key words: Placenta, Pregnancy, Sulfate

(J. Reprod. Dev. 57: 444-449, 2011)

S ulfate $\left(\mathrm{SO}_{4}{ }^{2-}\right)$ is vital for many processes in fetal growth and development, including neurogenesis and steroid metabolism [1-3]. The ratio of sulfonated (inactive) to unconjugated (active) steroids has important implications for many of the steroid-responsive events that regulate placental and fetal growth [4]. For example, placental estradiol-3-sulfate is taken up by the fetal brain, where it is desulfonated by steroid sulfatase to estradiol, which acts as a potent stimulator of fetal adrenocorticotropin secretion and the hypothalamus-pituitary-adrenal axis [5]. In addition, sulfonation of structural components, such as heparan sulfate proteoglycans (HSPGs), is essential for the maintenance of normal structure and function of placental and fetal tissues [6]. Together, these findings demonstrate an important role for sulfate in maintaining steroid and glycosaminoglycan homeostasis in the developing fetus.

$\mathrm{SO}_{4}{ }^{2-}$ is obtained from the diet and from the intracellular metabolism of methionine and cysteine [6]. Circulating $\mathrm{SO}_{4}{ }^{2-}$ levels are maintained by the NaS1 sulfate transporter which is expressed in the kidney where it mediates sulfate reabsorption [7]. During pregnancy, maternal blood sulfate levels increase by approximately 2fold which provides an essential supply to the placenta and developing fetus [8-11]. This increase in circulating sulfate level is correlated with increased maternal renal sulfate reabsorption [9, 12]. Since the fetus has a relatively low capacity to form sulfate from methionine and cysteine $[13,14]$, most of its sulfate must come from the maternal circulating sulfate pool. These findings are relevant to the decreased fecundity of NaS1 knockout $\left(\mathrm{Nas}^{-/}\right)$ mice which exhibit both hyposulfataemia and mid-gestational mis-

Received: November 9, 2010

Accepted: February 22, 2011

Published online in J-STAGE: March 8, 2011

(C)2011 by the Society for Reproduction and Development

Correspondence: PA Dawson (e-mail: paul.dawson@mmri.mater.org.au),

D Markovich (e-mail: d.markovich@uq.edu.au) carriage [15]. Fetal loss also occurs in heparan $\left(H_{s} 3 t 1^{-/-}\right)$and estrogen (Sult1 1 $^{-/}$) sulfotransferase null mice [16, 17], indicating that sulfonation plays a critical role in maintaining pregnancy.

Since NaS1 is not expressed in the placenta or fetus [7, 18], we used pregnant $\mathrm{Nasl}^{-/}$mice as a model for investigating the physiological consequences of maternal hyposulfataemia on placental, fetal and postnatal growth and development. From the matings of $\mathrm{Nas}^{-/-}$female $\times \mathrm{Nasl}^{+/+}$male mice and $\mathrm{Nasl}^{+/+}$female $\times \mathrm{Nas}^{-/-}$ male mice, which generates $\mathrm{Nas}^{+/-}$progeny in all litters, we show that pregnant $\mathrm{Nas}^{- \text {- }}$ mice have reduced maternal serum and amniotic fluid sulfate levels throughout pregnancy, negligible fetal serum sulfate levels, increased fetal reabsorptions, decreased fetal/ placental weight ratios, enlarged placental spongiotrophoblast and labyrinth layers and increased post-natal growth in offspring.

\section{Materials and Methods}

Animals

All procedures were carried out in accordance with the University of Queensland Animal Ethics Office. We previously generated $\mathrm{NaS}^{- \text {-- }}$ mice in which the NaS1 gene was disrupted by targeted mutagenesis [15]. Male and virgin female mice with a mixed genetic background (129Sv and C57BL/6) were mated overnight using the breeding strategy: $\mathrm{Nas}^{-/-}$female $\times \mathrm{Nas}^{\mathrm{I}^{++}}$male; and $\mathrm{NaSl}^{+/+}$female $\times \mathrm{Nasl}^{-/-}$male. This strategy produces $\mathrm{Nas}^{+/-}$ progeny in all litters, and compares placental, fetal and post-natal phenotypes between maternal hyposulfataemic $\mathrm{NaS1}^{-/-}$and normosulfataemic $\mathrm{Nas}^{+/+}$mice. Male $\mathrm{Nasl}^{-/-}$mice have normal fertility [15] and are therefore unlikely to reduce fecundity in our study. The presence of a copulatory plug in the morning was designated as embryonic day 0.5 (E0.5). Female mice were singly housed in conventional conditions and fed a standard rodent chow (no. AIN93G: Glen Forrest Stockfeeders, Glen Forrest, Western Australia) and 
water ad libitum. Females were randomly selected on E7.5, E12.5 and E18.5 of pregnancy to be euthanized for analysis of fetal and placental tissues. All procedures were carried out in accordance with the University of Queensland Animal Ethics Office.

\section{Biochemical analyses}

Adult mouse blood was collected from the submandibular vein using an animal bleeding lancet (MEDIpoint). Fetal blood was collected immediately following decapitation. Amniotic fluid was collected by needle aspiration. Serum and amniotic fluid sulfate was measured using a modified turbidometric assay as previously described [19].

\section{Histological analyses}

Tissues were dissected into approximately 50 volumes of buffered $10 \%$ formaldehyde and fixed for 3 days prior to paraffin embedding. Embedded tissue was sectioned, stained with H\&E, and examined by light microscopy.

\section{In situ hybridization}

Tissues were dissected into 4\% paraformaldehyde in PBS and fixed for 1 day at $4 \mathrm{C}$. Samples were processed, sectioned and probed with a spongiotrophoblast-specific marker (Prl7a2) as previously described [20]. The labyrinth, spongiotrophoblast and decidua/mesometrial triangle areas were outlined from digital images of the spongiotrophoblast-stained placental sections using a digitizing pen and measured using Image Pro Plus software (Media Cybernetics). A stage micrometer was used to calibrate the measurements.

\section{Quantitative real-time PCR ( $q R T-P C R)$ analysis of placental gene expression}

Total RNA was isolated from the placentae of female $\mathrm{NaSl}^{+/+}$ and $\mathrm{Nas}^{-1-}$ mice at $0900 \mathrm{~h}$, using previously described methods [15]. We examined the mRNA levels of 2 placental sulfate transporter genes (Slc13a4 and Slc26a2) and 2 sulfotransferase genes (Sult1el and Hs3st1). Total RNA (2 $\mu \mathrm{g}$ ) was reverse transcribed by using random hexamers and an Omniscript RT kit (Qiagen) as recommended by the manufacturer. PCR was performed in quadruplicate with $5 \mu \mathrm{l}$ cDNA (from 25 ng RNA) and $10 \mu$ mastermix containing Fast SYBR Green Master Mix (Applied Biosystems) and $200 \mathrm{nM}$ forward and reverse primers (Supplementary Table 1) in a 7500 FAST real time PCR system (Applied Biosystems, Scoresby, Australia). The thermal cycling protocol was: $50 \mathrm{C}$ for 2 min; $94 \mathrm{C}$ for $2 \mathrm{~min}$; 45 cycles of $94 \mathrm{C}$ for $1 \mathrm{sec}, 60 \mathrm{C}$ for $10 \mathrm{sec}$, and $72 \mathrm{C}$ for $15 \mathrm{sec}$. RNA expression levels and absolute threshold cycle values (Ct values) of each gene were normalised to those of ribosomal RNA with the manufacturer's software (Applied Biosystems). Amplification specificity was confirmed by melting curve analysis and agarose gel electrophoresis.

\section{Behavioural testing}

Same-litter groups of male or virgin female mice were housed $2-5$ per cage $(25 \times 42 \times 12 \mathrm{~cm})$ at a constant temperature $(23 \pm 1 \mathrm{C})$ with a $12 \mathrm{~h}$ light/dark cycle (lights on at 0600 and off at $1800 \mathrm{~h}$ ). To facilitate adaptation, mice were transported to the behavioural studies facility at least $24 \mathrm{~h}$ prior to testing. Experiments were conducted between 0800 and $1300 \mathrm{~h}$ with the lighting level adjusted to 100 lux. Other than the brief testing periods, mice had access to food and water ad libitum. One group of mice was tested sequentially in the marble bury and open field tests with a one week interval. A second group of mice was tested in the elevated plus maze. Behavioural testing was performed as previously described [21].

\section{Statistical analyses}

Data were analysed using GraphPad Prism (Version 5.01, GraphPad Software, La Jolla, CA, USA). Where data were normally distributed, the statistical significance of differences between $\mathrm{Nasl}^{+/+}$and $\mathrm{Nas}^{\mathrm{I}^{-/}}$groups was assessed by an unpaired Student's $t$-test, with $\mathrm{P}<0.05$ considered significant. Differences in fetal, placental and maternal weights, and placental areas, were analysed by the Dunnett Multiple comparison test, with $\mathrm{P}<0.05$ considered significant.

\section{Results}

\section{Biometry}

Fetal numbers and reabsorptions: Previously, we reported reduced litter sizes in progeny from female $\mathrm{Nas}^{-/}$mice $(\mathrm{n}=4.1 \pm$ 3.9) when compared to $\mathrm{Nasl}^{+/+}(\mathrm{n}=10.7 \pm 2.5)$ mice [15]. In order to characterize this further, here we determined the number of fetuses and reabsorption sites in pregnant $\mathrm{Nasl}^{-/-}$and $\mathrm{Nasl}^{+/+}$mice at embryonic days E7.5, E12.5 and E18.5 (Fig. 1A, B). At E7.5, we found similar numbers of fetuses and reabsorption sites in pregnant $\mathrm{Nas}^{-/-}$and $\mathrm{Nas}^{+/+}$mice. However, fetal numbers were significantly reduced (by $\geq 50 \%$ ) in $\mathrm{Nas}^{-/}$mice at E12.5 (median=4, $\mathrm{P}=$ 0.003 ) and E18.5 (median=3, P=0.015) when compared with pregnant $\mathrm{Nas}^{+/+}$mice (median=8). These findings were supported by a significantly increased number of fetal reabsorption sites in pregnant $\mathrm{NaSl}^{- \text {- }}$ mice at E18.5 (Fig. 1B).

Maternal, fetal and placental weights: The increase in body weight of pregnant $\mathrm{Nas}^{-/-}$mice at E12.5 (by $\approx 21 \%$ ) and E18.5 (by $\approx 50 \%$ ) was significantly less than pregnant $\mathrm{Nas}^{+/+}$mice at E12.5

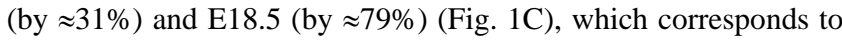
the reduced number of fetuses found in $\mathrm{Nas}^{-/}$mice (Fig. 1A). At E12.5 and E18.5, there were slight (but non-significant) decreases in fetal weights and increased placental weights in pregnant $\mathrm{Nas}^{1-1}$ mice when compared with $\mathrm{Nas}^{1^{++}}$mice (data not shown). As an indicator of placental efficiency, we determined the fetal:placental weight ratios. No difference was observed at E12.5 but a significant reduction was observed at E18.5 (by $\approx 25 \%, \mathrm{P}=0.005$ ) in $\mathrm{Nas}^{-1}$ mice $(8.9 \pm 0.5, \mathrm{n}=20)$ when compared to $\mathrm{Nas}^{1^{++}}$mice $(11.8 \pm 0.4$, $\mathrm{n}=42$ ) (Fig. 1D).

\section{Fetal and placental morphology}

The important roles of sulfonation in brain and bone development [3, 22], led us to compare these tissues in fetuses from pregnant $\mathrm{Nasl}^{-/-}$and $\mathrm{NaSl}^{+/+}$mice. Histological analyses of fetal brain and bone at E12.5 revealed no gross structural differences in $\mathrm{NaSl}^{-/-}$and $\mathrm{NaSl}^{+/+}$mice (data not shown). As placental weights appeared to be slightly increased in pregnant $\mathrm{Nas}^{-/-}$mice, we ana- 

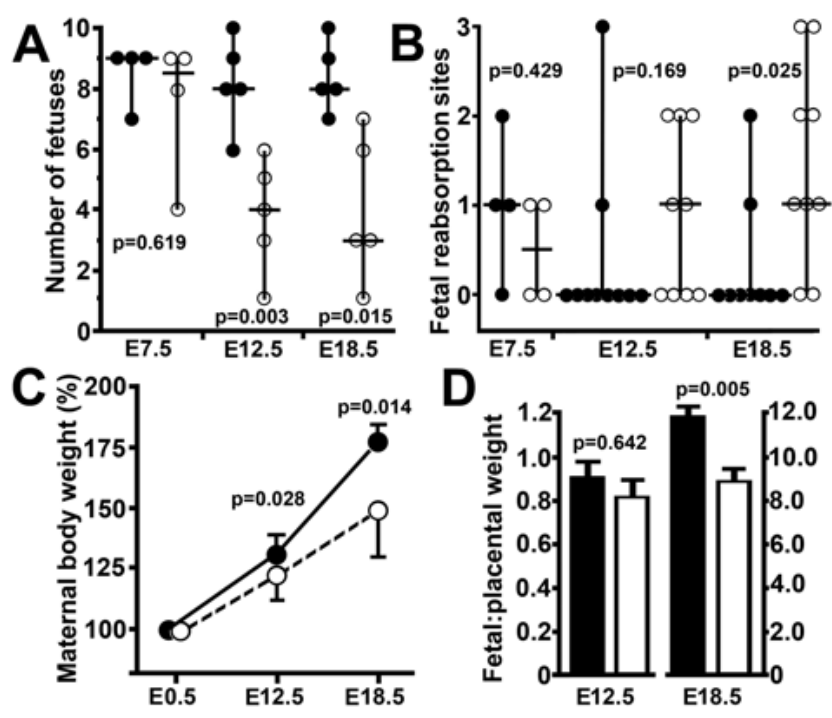

Fig. 1. Maternal, fetal and placental biometry data from the matings of $\mathrm{Nasl}^{+/+}$female $\times \mathrm{Nas}^{-{ }^{--}}$male mice (filled circles) and $\mathrm{Nasl}^{-/-}$ female $\times \mathrm{Nas}^{+/+}$male mice (open circles). (A) Fetal and (B) reabsorption site numbers, range, median and $\mathrm{P}$ values showing a reduced number of fetuses and an increased number of fetal reabsorptions in $\mathrm{Nas}^{-/}$mice at E12.5 and E18.5. n=4-10 per gestational time point. (C) Maternal $\mathrm{Nas}^{-/-}$body weights (\% increase, $n=5-11$, mean, SD) were reduced at E12.5 and E18.5 when compared to $\mathrm{Nas}^{+/+}$mice. (D) Ratio of fetal to placental weights in $\mathrm{Nasl}^{+/+}$(n=19-20, filled bars) and $\mathrm{Nas}^{-/-}(\mathrm{n}=41-42$, unfilled bars) mice, showing a decreased placental efficiency in $\mathrm{Nas}^{-1-}$ mice at E18.5. Mean, SE and P values from a multiple comparisons test.

lyzed the morphology of the labyrinth and spongiotrophoblast layers as well as the maternal components of the placenta, the decidua/mesometrial triangle. Spongiotrophoblast staining allowed for the clear demarcation of the placental layers (Fig. 2A,B). The decidua/mesometrial triangle area was similar in size between pregnant $\mathrm{Nasl}^{-/}\left(7.2 \pm 0.9 \mathrm{~mm}^{2}\right)$ and $\mathrm{Nasl}^{+/+}(8.4 \pm 1.6$ $\mathrm{mm}^{2}$ ) mice, whereas labyrinth and spongiotrophoblast areas were increased by $\approx 2.4$-fold in placentas from pregnant $\mathrm{Nas}^{-1 /}$ mice (5.2 $\pm 1.7 \mathrm{~mm}^{2}, 3.2 \pm 1.0 \mathrm{~mm}^{2}$ ) when compared to pregnant $\mathrm{Nas}^{+/+}$ mice $\left(2.2 \pm 0.9 \mathrm{~mm}^{2}, 1.3 \pm 0.5 \mathrm{~mm}^{2}\right)$ (Fig. 2C-E).

\section{Serum and amniotic fluid sulfate levels}

In order to determine if body sulfate levels were altered in pregnant $\mathrm{Nas}^{-1-}$ mice, we measured circulating sulfate levels in pregnant $\mathrm{Nas}^{-{ }^{-/}}$and $\mathrm{NaSl}^{+/+}$mice at three time points after conception (Fig. 3A). Day 7.5 was chosen as the earliest time point to study sulfate levels because this gestational age is before signs of reabsorptions at E12.5 (Fig. 1B). Serum sulfate levels were significantly $(\mathrm{P}<0.05)$ increased (by $\approx 2$-fold) in pregnant $\mathrm{Nas}^{+/+}$mice, with levels peaking at E12.5 ( $2.3 \pm 0.8 \mathrm{mM})$, but remained low (0.5 $\mathrm{mM}$ ) throughout pregnancy in $\mathrm{Nas}^{-1}$ mice (Fig. 3A). Serum sulfate levels (Fig. 3B) were markedly lower (by $\approx 30$-fold) in E18.5 fetuses from $\mathrm{Nas}^{-/-}$mice $(0.05 \pm 0.01 \mathrm{mM})$ when compared to

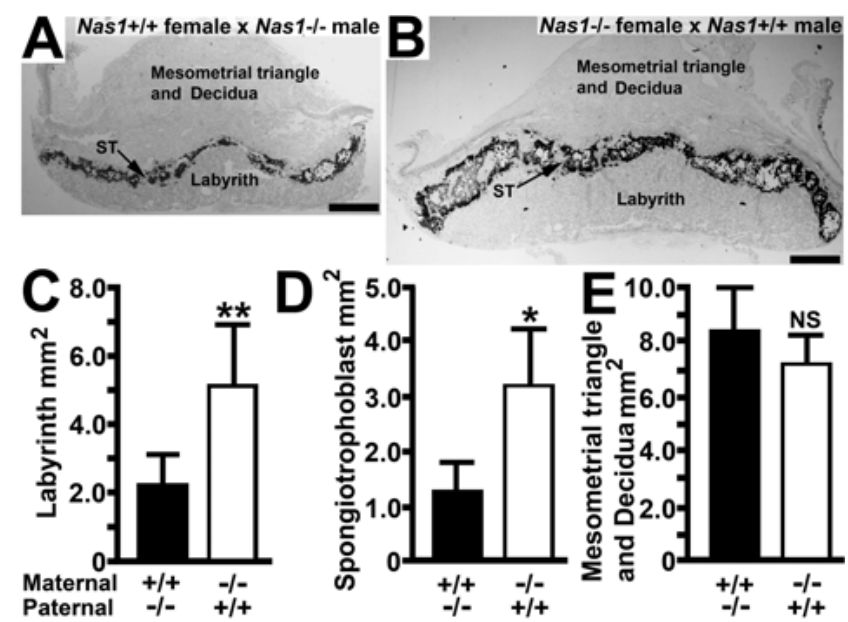

Fig. 2. Enlarged labyrinth and spongiotrophoblast (ST) layers in E12.5 placentae from pregnant $\mathrm{NaS1}^{-/-}$mice when compared to pregnant $\mathrm{Nasl}^{+/+}$mice. (A and B) Representative sections from the center of placentae probed with a spongiotrophoblast-specific riboprobe (Prl7a2). Bar, $1 \mathrm{~mm}$. (C) Labyrinth and (D) spongiotrophoblast areas were enlarged in placentae from maternal $\mathrm{Nas}^{-{ }^{--}}$mice when compared to maternal $\mathrm{Nas}^{+/+}$mice, whereas (E) decidua/mesometrial triangle area were similar in placentae from pregnant $\mathrm{Nas}^{\mathrm{I}^{--}}$and $\mathrm{Nasl}^{\mathrm{H}^{+/}}$mice. Mean $\pm \mathrm{SD}$, $\mathrm{n}=9$ per group. ${ }^{* *} \mathrm{P}<0.001, * \mathrm{P}<0.01$ and NS, non-significant, when compared to placentae from pregnant $\mathrm{Nasl}^{+/+}$mice.

$\mathrm{Nas}^{+/+}$mice $(1.53 \pm 0.20 \mathrm{mM})$. Amniotic fluid sulfate levels (Fig. 3C) were significantly lower in $\mathrm{Nas}^{-/}$mice when compared to $\mathrm{Nas}^{+/+}$mice at E12.5 (by $\approx 3$-fold) and at E18.5 (by $\approx 9$-fold).

\section{Placental gene expression}

Previously, we showed an altered hepatic transcriptional profile

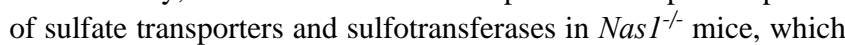
we proposed to be a compensatory response to hyposulfataemia [23]. In this study, we quantitated the mRNA levels of two sulfate transporters (Slc13a4 and Slc26a2) and two sulfotransferases (Sult1e1 and Hs3st1), which are normally expressed in mouse placenta [16, 17, 24-25], from E12.5 and E18.5 placentae of pregnant $\mathrm{Nas}^{-{ }^{-/}}$and $\mathrm{Nas}^{+/ /+}$mice. No significant differences were found for Slc13a4, Slc26a2, Sult1e1 and Hs3st1 mRNA levels (Supplementary Table 2).

\section{Postnatal growth}

Our previous findings of growth retardation in $\mathrm{Nas}^{--}$mice [15], led us to investigate the consequences of fetal hyposulfataemia (Fig. 3B) on post-natal growth. As an indicator of growth, we measured the body weights and tail lengths of progeny from $\mathrm{Nas}^{-1-}$ and $\mathrm{Nas}^{+/+}$mice. At birth, body weights were slightly increased (by $\approx 7 \%, \mathrm{P}<0.05)$ in male $(1.59 \pm 0.04 \mathrm{~g}, \mathrm{n}=25)$ and female $(1.54 \pm$ $0.05 \mathrm{~g}, \mathrm{n}=23)$ progeny from maternal $\mathrm{Nas}^{-1-}$ mice when compared to male $(1.47 \pm 0.02 \mathrm{~g}, \mathrm{n}=31)$ and female $(1.45 \pm 0.02 \mathrm{~g}, \mathrm{n}=38)$ progeny from maternal $\mathrm{Nas}^{+/+}$mice (Fig. 4). At 1 week of age, body weights of male and female mice were similar between groups, and were not significantly different in male mice up to 16 


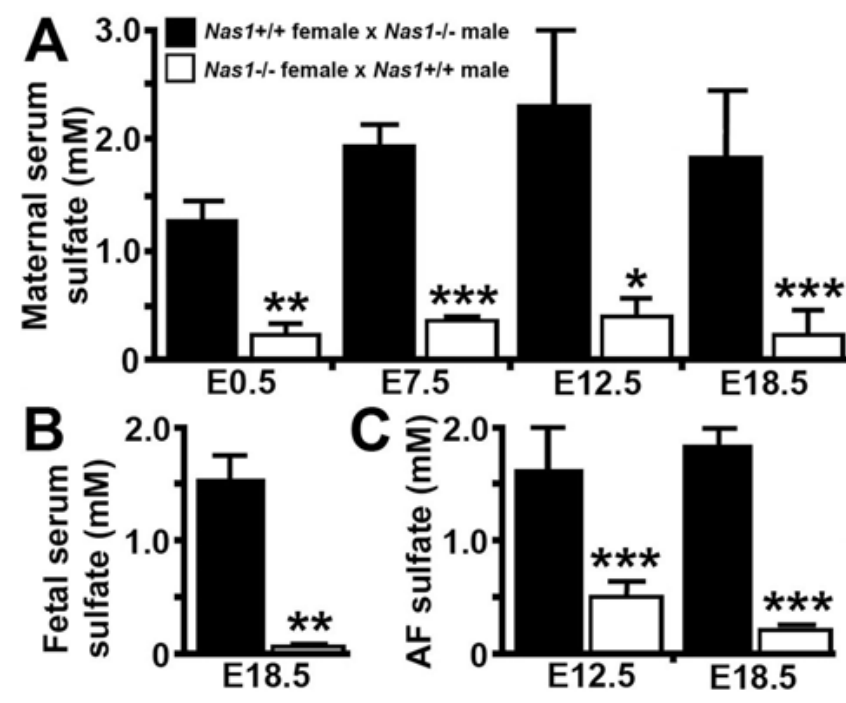

Fig. 3. Serum and amniotic fluid (AF) sulfate levels in maternal $\mathrm{Nasl}^{+/+}$ and $\mathrm{Nas}^{-/}$mice ( $\mathrm{n}=4$ to 5 per group). Sulfate levels remain low in (A) maternal and (B) fetal serum, and (C) amniotic fluid from progeny of $\mathrm{Nas}^{-/-}$female $\times \mathrm{NaSl}^{+/+}$male mice (open bars) when compared to progeny of $\mathrm{Nas}^{+/+}$female $\times \mathrm{Nas}^{-/-}$male mice (filled bars). Data are means $\pm \mathrm{SE} . * \mathrm{P}<0.05, * * \mathrm{P}<0.01$ and *** $\mathrm{P}<0.001$ when compared to $\mathrm{Nas}^{+/+}$mice.

weeks. From 5 to 16 weeks of age, body weights were increased (by $\approx 10 \%, \mathrm{P}<0.05$ ) in the female progeny of maternal $\mathrm{Nas}^{-{ }^{-}}$mice when compared to female progeny from maternal $\mathrm{Nas}^{+/+}$mice (Fig. 4B). Tails lengths of male and female offspring were similar between groups from 1 to 16 weeks of age (data not shown).

\section{Behavioural studies of progeny from $\mathrm{Nas}^{-/-}$and $\mathrm{Nas}^{+/+}$mice}

To determine the consequences of maternal and fetal hyposulfataemia on post-natal behaviour, we conducted behavioural testing on the adult progeny of maternal $\mathrm{Nasl}^{-/-}$and $\mathrm{Nasl}^{+/+}$mice. No significant differences were found between groups in the elevated plus maze, open field and marble bury tests (data not shown).

\section{Discussion}

In this study, we show markedly reduced sulfate levels in the serum of maternal $\mathrm{Nas}^{-/}$mice and in fetal serum and amniotic fluid of their progeny. From mid-gestation, pregnant $\mathrm{NaSl}^{-/}$mice have enhanced fetal reabsorption, enlarged placental labyrinth and spongiotrophoblast layers and decreased fetal numbers. The progeny of maternal $\mathrm{Nasl}^{-/}$mice show increased body weight at birth, and female progeny have increased body weight in adulthood. Since all progeny from the reciprocal matings in this study were $\mathrm{Nas}_{1}{ }^{+-}$, and because NaS1 is not expressed in the placenta or fetus $[7,18]$, we propose that these abnormal features are due to reduced sulfate supply from maternal circulation to the fetoplacental unit as a consequence of maternal hyposulfataemia.

Previous human studies showed that maternal serum sulfate levels increased (by $\approx 2$-fold) during pregnancy [9, 11, 12]. These
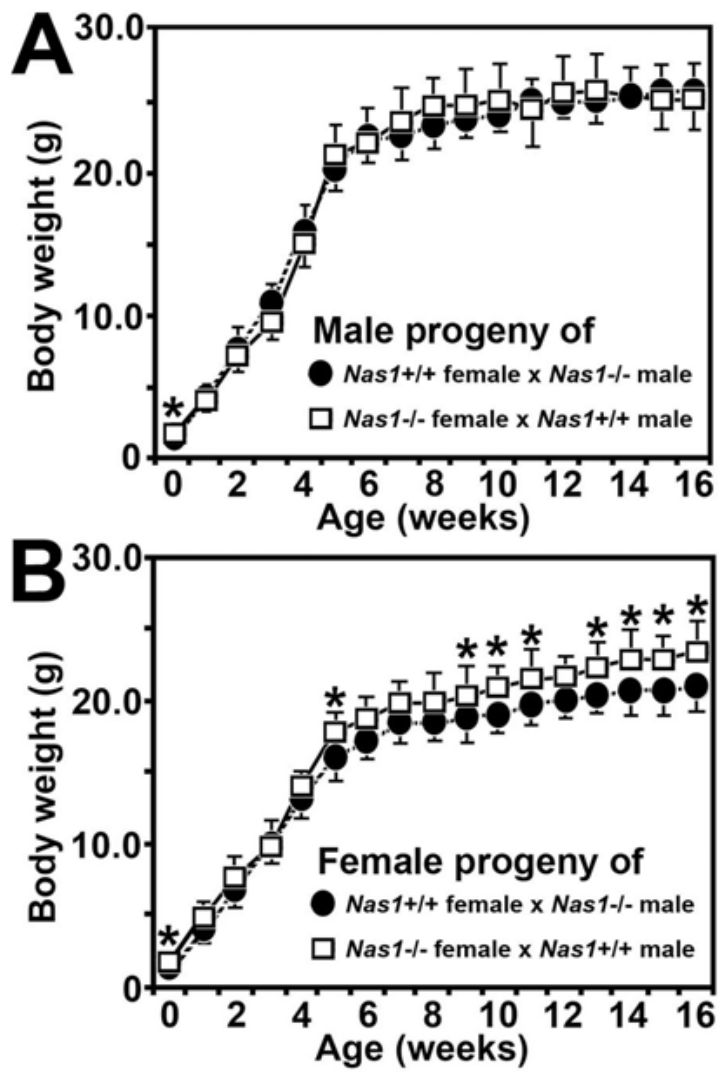

Fig. 4. Body weights of progeny from $\mathrm{Nas}^{+/+}$female $\times \mathrm{Nas}^{-/-}$male mice (filled circles and dash line) and $\mathrm{Nas}^{-/-}$female $\times \mathrm{Nasl}^{+/+}$ male mice (open squares and solid line). (A) Male and (B) female body weights were determined up to 16 weeks of age. Each point represents the mean \pm SD derived from 6 to 37 measurements. ${ }^{*} \mathrm{P}<0.05$ when compared to progeny of $\mathrm{Nasl}^{+/+}$ female mice.

findings led us to investigate circulating sulfate levels in pregnant $\mathrm{Nas}^{-/-}$mice and compare them with pregnant $\mathrm{NaS}^{+/+}$mice. Our data demonstrate that $\mathrm{NaS} 1$ is essential for maintaining high maternal circulating sulfate levels throughout pregnancy, and that maternal hyposulfataemia leads to markedly reduced fetal serum and amniotic fluid sulfate levels. This is an important finding because the placenta and fetus have a relatively low capacity to generate sulfate $[13,14]$, and rely on a sufficient supply of sulfate from the mother's circulation for sulfonation reactions to function [2]. Whilst the precise effect of hyposulfataemia on sulfonation in the placenta and fetus is at present unclear, our data demonstrate that loss of NaS1 causes reduced fecundity via maternal hyposulfataemia throughout pregnancy which leads to reduced fetal and amniotic fluid sulfate levels in $\mathrm{Nasl}^{-/}$mice.

Reduced litter sizes arising from $\mathrm{Nas}^{\mathrm{Y}^{--}}$female mice [15] led us to study the viability and growth of fetuses in pregnant $\mathrm{Nas}^{-/-}$and $\mathrm{NaS}^{+/+}$mice at three gestational ages that frame the period of chorioallantoic placental development: E7.5, prior to chorioallontoic attachment and any fetal losses in $\mathrm{NaS}^{-/-}$pregnancies; E12.5, when a functional placental labyrinth is present, which is the site of 
fetal-maternal exchange [26]; and near the end of gestation at E18.5, when labyrinth development continues and rapid fetal growth is occurring [27]. In this study, we show similar numbers of viable fetuses in pregnant $\mathrm{Nasl}^{-/}$and $\mathrm{NaSl}^{+/+}$mice at E7.5, indicating no change in fertility in $\mathrm{Nas}^{-/}$mice per se. The reduced number of viable fetuses in pregnant $\mathrm{Nas}^{-/-}$mice at E12.5 and E18.5 were similar to the number of live births previously reported [15], suggesting that fetal loss occurs prior to day E12.5. This conclusion is consistent with the increased fetal reabsorption sites found in pregnant $\mathrm{NaS}^{-{ }^{-}}$mice at E12.5 and E18.5, as well as our earlier observations of blood spotting and miscarriage in $\mathrm{Nas}^{-/}$ mice at 14 days of gestation [15]. Whilst fetal numbers were reduced by $\approx 50 \%$ in $\mathrm{Nas}^{-/}$mice at E12.5 and E18.5, we found similar weights of fetuses from $\mathrm{Nasl}^{-/-}$and $\mathrm{Nas}^{+/+}$pregnant mice. A hallmark feature of normal rodent pregnancy is the inverse relationship between fetal number and weight [28, 29], which was not found in E12.5 and E18.5 fetuses from pregnant $\mathrm{Nas}^{-/-}$mice. This finding implies that the reduced number of surviving fetuses $(\approx 4$ per pregnancy) in pregnant $\mathrm{Nas}^{-/-}$mice have no growth advantage up to at least E18.5, when compared to fetuses ( $\approx 8$ per pregnancy) from pregnant $\mathrm{Nas}^{+/+}$mice. This can be relevant to the enlarged labyrinth layer in pregnant $\mathrm{Nas}^{- \text {- }}$ mice, which may be compensating for a reduction in available sulfate. Enlargement of the labyrinth is proposed to be a physiological adaptation to maximize nutrient transfer in the placenta, as shown in a mouse model of over-expression of maternal IGFBP1 [30]. In addition, since impaired IGF1 expression can reduce fecundity and placental nutrient exchange [31], it is possible that low levels of IGF1 in $\mathrm{Nasl}^{-/}$ mice [15] may be a contributing factor to the reduced fecundity and/or altered placental morphometry in pregnant $\mathrm{NaS}^{-{ }^{--}}$mice. To our knowledge, this is the first study to show increased fetal reabsorption and altered placental morphology in a model of maternal hyposulfataemia.

Enlargement of the spongiotrophoblast layer in mouse placentae has been observed in several mouse models with decreased fetal survival, including over-expression of epidermal growth factor receptor [32], trisomy 15 syndrome [33] and hydroxysteroid $17 \beta$ dehydrogenase 2 null mice [34]. This is relevant to the enlarged spongiotrophoblast layer in placentae from pregnant $\mathrm{Nasl}^{-/}$mice, which have enhanced mid-gestational fetal loss. Spongiotrophoblasts produce numerous proteins with endocrine activity, including cytokines, prolactin-like hormones and lactogens [35], which are essential for the maintenance and progression of pregnancy and development of the fetus [36-38]. Whilst the precise mechanism underlying the placental phenotype in $\mathrm{Nas}^{-{ }^{--}}$mice is at present not clear, our data demonstrate maternal hyposulfataemia accompanies an enlarged spongiotrophoblast layer.

Sulfotransferase (Sult1e1, Hs 3st1 and Tpst1) null mice exhibit mid-gestational fetal loss [16, 17, 39], indicating that sulfonation of estrogen, heparan sulfate and tyrosine, is critical for maintaining pregnancy. Our previous study demonstrated increased hepatic sulfotransferase and Satl sulfate transporter mRNA levels in $\mathrm{Nas1}^{- \text {- }}$ mice [23], suggesting that sulfotransferase and sulfate transporter mRNA expression is sensitive to changes in blood sulfate levels. In this study we investigated the mRNA expression of two sulfotransferases (Sult1el and $\mathrm{Hs}_{s} \mathrm{st} 1$ ) and two sulfate transporters ( $\mathrm{NaS2}$ and Slc26a2), which are expressed in the placenta [16, 17, 24, 25]. However, our data show no change in Sult1e1, Hs 3st1, NaS2 and Slc26a2 mRNA expression, indicating that these genes in the placenta are not sensitive to changes in maternal circulating sulfate levels.

The abnormal prenatal phenotypes of placental and fetal tissues from pregnant $\mathrm{Nas}^{-/}$mice led us to investigate the postnatal growth of progeny from $\mathrm{Nas}^{-/-}$and $\mathrm{NaS}^{+/+}$female mice. Whilst the median fetal weight was similar in pregnant $\mathrm{Nasl}^{-/}$and $\mathrm{Nasl}^{+/+}$ mice at E18.5, we found significantly increased (by $\approx 7 \%$ ) birth weights of male and female progeny from maternal $\mathrm{Nas}^{-/-}$mice when compared to the progeny of maternal $\mathrm{Nas}^{+/+}$mice, suggesting late prenatal accelerated growth in pregnant $\mathrm{Nasl}^{-/-}$mice. Previous studies showed accelerated fetal growth from mid- to lategestation [40] and a greater mass at weaning [41] in the progeny of rats fed on a low protein diet during pregnancy. Interestingly, the body mass of female progeny from maternal $\mathrm{Nas}^{-/-}$mice was increased (by 10\%) from 5 weeks of age when compared to female progeny of maternal $\mathrm{NaS}^{+/+}$mice, which was not observed between male progeny from maternal $\mathrm{Nasl}^{-/}$and $\mathrm{Nasl}^{+/+}$mice, indicating that male and female progeny may not have identical responses to maternal hyposulfataemia. Previous studies have shown that female post-natal growth is more responsive to intrauterine stressors when compared to males [42], suggesting that gender differences are associated with metabolic programming in the developing fetus.

Our earlier studies showed behavioural abnormalities in $\mathrm{Nas}^{-1-}$ mice, including reduced object anxiety and locomotor activity [21]. In this study, we found no behavioural differences between adult progeny from maternal $\mathrm{NaS}^{-/-}$and $\mathrm{NaS}^{+/+}$mice in marble bury, elevated plus maze and open field tests, which are used to assess anxiety-like behaviours in rodents [43-45]. These findings indicate that exposure to maternal and fetal hyposulfataemia does not lead to anxiety-like symptoms in the adult progeny from $\mathrm{Nas}^{-/-}$ female mice.

In summary, this study shows that NaS1 is essential for maintaining high circulating sulfate levels during pregnancy and that maternal hyposulfataemia leads to mid-gestational fetal loss, altered placental development and increased birth weights. These findings are relevant to diet, hormones and analgesics which regulate blood sulfate levels [46], prompting future assessment of preand post-natal development in humans with altered sulfate homeostasis.

\section{Acknowledgements}

The authors would like to thank V Kelly (School of Biomedical Sciences, University of Queensland) and Drs L Richards and T Burne (Queensland Brain Institute, Brisbane, Australia) for their assistance. This study was funded by grants from the National Health and Medical Research Council of Australia.

\section{References}

1. Falany CN. Enzymology of human cytosolic sulfotransferases. FASEB J 1997; 11: 206216.

2. Klassen CD, Boles J. The importance of 3'-phosphoadenosine 5'-phosphosulfate 
(PAPS) in the regulation of sulfation. FASEB J 1997; 11: 404-418.

3. Strott CA. Sulfonation and molecular action. Endocr Rev 2002; 23: 703-732.

4. Strott CA. Steroid sulfotransferases. Endocr Rev 1996; 17: 670-697.

5. Wood CE. Estrogen/hypothalamus-pituitary-adrenal axis interactions in the fetus: The interplay between placenta and fetal brain. J Soc Gynecol Investig 2005; 12: 67-76.

6. Mulder GJ, Jakoby WB. Sulfation. In: Mulder GJ (ed.), Conjugation Reactions in Drug Metabolism: An Integrated Approach: Substrates, Co-substrates, Enzymes and Their Interactions In Vivo and In Vitro. Taylor and Francis, London; 1990: 107-161.

7. Lee A, Beck L, Markovich D. The human renal sodium sulfate cotransporter (SLC13A1; hNaSi-1) cDNA and gene: organisation, chromosomal localization, and functional characterization. Genomics 2000; 70: 354-363.

8. Cole DE, Baldwin LS, Stirk LJ. Increased inorganic sulfate in mother and fetus at parturition: evidence for a fetal-to-maternal gradient. Am J Obstet Gynecol 1984; 148: 596599

9. Cole DE, Baldwin LS, Stirk LJ. Increased renal reabsorption of inorganic sulfate in third-trimester high-risk pregnancies. Obstet Gynecol 1985; 66: 485-490.

10. Morris ME, Levy G. Plasma inorganic sulfate concentrations in pregnant women. J Pharm Sci 1983; 72: 715-716.

11. Tallgren LG. Inorganic sulphate in relation to the serum thyroxine level and in renal failure. Acta Med Scand 1980; Suppl 640: 1-100.

12. Lee HJ, Balasubramanian SV, Morris ME. Effect of pregnancy, postnatal growth, and gender on renal sulfate transport. Proc Soc Exp Biol Med 1999; 221: 336-344.

13. Gaull G, Sturman JA, Raiha NC. Development of mammalian sulfur metabolism: absence of cystathionase in human fetal tissues. Pediatr Res 1972; 6: 538-547.

14. Loriette $\mathbf{C}$, Chatagner F. Cysteine oxidase and cysteine sulfinic acid decarboxylase in developing rat liver. Experientia 1978; 34: 981-982.

15. Dawson PA, Beck L, Markovich D. Hyposulfatemia, growth retardation, reduced fertility and seizures in mice lacking a functional $\mathrm{NaS}_{\mathrm{i}}-1$ gene. Proc Natl Acad Sci USA 2003; 100: 13704-13709.

16. de Agostini A. An unexpected role for anticoagulant heparan sulfate proteoglycans in reproduction. Swiss Med Wkly 2006; 136: 583-590.

17. Tong MH, Jiang H, Liu P, Lawson JA, Brass LF, Song WC. Spontaneous fetal loss caused by placental thrombosis in estrogen sulfotransferase-deficient mice. Nat Med 2005; 11: 153-159.

18. Stuart RO, Bush KT, Nigam SK. Changes in global gene expression patterns during development and maturation of the rat kidney. Proc Natl Acad Sci USA 2001; 98: 56495654 .

19. Lee S, Dawson PA, Hewavitharana AK, Shaw PN, Markovich D. Disruption of NaS1 sulfate transport function in mice leads to enhanced acetaminophen-induced hepatotoxicity. Hepatology 2006; 43: 1241-1247.

20. Simmons DG, Rawn S, Davies A, Hughes M, Cross JC. Spatial and temporal expression of the 23 murine Prolactin/Placental Lactogen-related genes is not associated with their position in the locus. BMC Genomics 2008; 9: 352.

21. Dawson PA, Steane SE, Markovich D. Behavioural abnormalities of the hyposulfataemic Nas1 knock-out mouse. Behav Brain Res 2004; 154: 457-463.

22. Superti-Furga A, Hastbacka J, Wilcox WR, Cohn DH, van der Harten HJ, Rossi A, Blau N, Rimoin DL, Steinmann B, Lander ES, Gitzelmann R. Achondrogenesis type IB is caused by mutations in the diastrophic dysplasia sulphate transporter gene. Nat Genet 1996; 12: 100-102.

23. Dawson PA, Gardiner B, Grimmond S, Markovich D. Transcriptional profile reveals altered hepatic lipid and cholesterol metabolism in hyposulfatemic NaS1 null mice. Physiol Genomics 2006; 26: 116-124.

24. Dawson PA, Pirlo KJ, Steane SE, Kunzelmann K, Chien YJ, Markovich D. Molecular cloning and characterization of the mouse $\mathrm{Na}+$ sulfate cotransporter gene (Slc13a4): Structure and expression. Genes Genet Syst 2006; 81: 265-272.

25. Haila S, Hastbacka J, Bohling T, Karjalainen-Lindsberg ML, Kere J, Saarialho-Kere U. SLC26A2 (diastrophic dysplasia sulfate transporter) is expressed in developing and mature cartilage but also in other tissues and cell types. J Histochem Cytochem 2001; 49:
973-982.

26. Cross JC, Simmons DG, Watson ED. Chorioallantoic morphogenesis and formation of the placental villous tree. Ann NY Acad Sci 2003; 995: 84-93.

27. Renfree MB, Hensleigh HC, McLaren A. Developmental changes in the composition and amount of mouse fetal fluids. J Embryol Exp Morphol 1975; 33: 435-446.

28. Cowley DE, Pomp D, Atchley WR, Eisen EJ, Hawkins-Brown D. The impact of maternal uterine genotype on postnatal growth and adult body size in mice. Genetics 1989; 122: 193-203.

29. Romero A, Villamayor F, Grau MT, Sacristán A, Ortiz JA. Relationship between fetal weight and litter size in rats: application to reproductive toxicology studies. Reprod Toxicol 1992; 6: 453-456.

30. Crossey PA, Pillai CC, Miell JP. Altered placental development and intrauterine growth restriction in IGF binding protein-1 transgenic mice. J Clin Invest 2002; 110 $411-418$.

31. Roberts CT, Owens JA, Sferruzzi-Perri AN. Distinct actions of insulin-like growth factors (IGFs) on placental development and fetal growth: lessons from mice and guinea pigs. Placenta 2008; 29: S42-S47.

32. Dackor J, Li M, Threadgill DW. Placental overgrowth and fertility defects in mice with a hypermorphic allele of epidermal growth factor receptor. Mamm Genome 2009 20: 339-349.

33. Hirning-Folz $\mathbf{U}$, Winking $\mathbf{H}$, Hameister $\mathbf{H}$. Aberrant Myc expression in the murine trisomy 15 syndrome is correlated with prolonged proliferation in spongiotrophoblast cells of the placenta. Cytogenet Cell Genet 1992; 61: 289-294.

34. Rantakari P, Strauss L, Kiviranta R, Lagerbohm H, Paviala J, Holopainen I, Vainio S, Pakarinen P, Poutanen M. Placenta defects and embryonic lethality resulting from disruption of mouse hydroxysteroid (17-beta) dehydrogenase 2 gene. Mol Endocrinol 2008; 22: 665-675.

35. Soares MJ. The prolactin and growth hormone families: pregnancy-specific hormones/cytokines at the maternal-fetal interface. Reprod Biol Endocrinol 2004; 2: 51.

36. Bowen JM, Chamley L, Mitchell MD, Keelan JA. Cytokines of the placenta and extra-placental membranes: biosynthesis, secretion and roles in establishment of pregnancy in women. Placenta 2002; 23: 239-256.

37. Mitchell MD, Trautman MS, Dudley DJ. Cytokine networking in the placenta. Placenta 1993; 14: 249-275.

38. Soares MJ, Müller H, Orwig KE, Peters TJ, Dai G. The uteroplacental prolactin family and pregnancy. Biol Reprod 1998; 58: 273-284

39. Ouyang YB, Crawley JT, Aston CE, Moore KL. Reduced body weight and increased postimplantation fetal death in tyrosylprotein sulfotransferase-1-deficient mice. J Biol Chem 2002; 277: 23781-23787.

40. Langley-Evans SC, Gardner DS, Jackson AA. Association of disproportionate growth of fetal rats in late gestation with raised systolic blood pressure in later life. J Reprod Fertil 1996; 106: 307-312.

41. Langley SC, Jackson AA. Increased systolic blood pressure in adult rats induced by fetal exposure to maternal low protein diets. Clin Sci (Lond) 1994; 86: 217-222.

42. Misra DP, Salafia CM, Miller RK, Charles AK. Non-linear and gender-specific relationships among placental growth measures and the fetoplacental weight ratio. Placenta 2009; 30: 1052-1057.

43. Carola V, D'Olimpio F, Brnamonti E, Mangia F, Renzi P. Evaluation of the elevated plus-maze and open field tests for the assessment of anxiety-related behaviour in inbred mice. Behav Brain Res 2002; 134: 49-57.

44. Njung'e K, Handley SL. Evaluation of marble-burying behavior as a model of anxiety. Pharmacol Biochem Behav 1991; 38: 63-67.

45. Rodgers RJ, Johnson JT. Factor analysis of spatiotemporal and ethological measure in the murine elevated-plus maze test of anxiety. Pharmacol Biochem Behav 1995; 52: 297-303.

46. Markovich D. Physiological roles and regulation of mammalian sulfate transporters. Physiol Rev 2001; 81: 1499-1534. 